Contents List available at RAZI Publishing

Earth Science Malaysia (ESMY)

Journal Homepage: http://www.razipublishing.com/journals/earth-sciences-malaysia-esm/

https://doi.org/10.26480/esmy.02.2017.17.22

\title{
DEEP MARINE BENTHIC FORAMINIFERAL FROM TEMBURONG FORMATION IN LABUAN ISLAND
}

\author{
Baharudin Bakar, Sanudin Hj. Tahir, Junaidi Asis \\ Geology Programme, Faculty of science and Natural Resources, University Malaysia Sabah, Kota Kinabalu, Sabah, Malaysia. \\ *Corresponding author email: baharudinbakar@gmail.com
}

This is an open access article distributed under the Creative Commons Attribution License, which permits unrestricted use, distribution, and reproduction in any medium, provided the original work is properly cited

\section{ARTICLE DETAILS}

\section{Article History:}

Received 7 July 2017

Accepted 10 October 2017

Available online 5 November 2017

\section{Keywords:}

The research was done with a total of 15 samples of mudstones and shale of Temburong Formation.

\section{ABSTRACT}

A paleontological research was conducted in Labuan in pursue of the foraminiferal species of benthic species. Fifteen mudstone samples from Temburong Formation were taken and successfully extracted an amount of benthic foraminifera. The Labuan Island is consists of two major depositional environment; deep-marine and shallowmarine environment, which is highly valuable geologically but the samples were all of Crocker Formation and Temburong Formation to investigate the fossils content of the turbidite sequence. The Temburong Formation comprises of mainly flysch deposit. All of the benthic foraminifers were processed and extracted accordingly using the standard paleontological method with additional method of adding $25 \mathrm{ml}$ to $30 \mathrm{ml}$ of Hydrogen peroxide. A total of 37 species were found and identified, consist of hyaline and agglutinated group. Thus, the Temburong Formation is considered as deep-sea deposition with the evidence of deep-marine agglutinated foraminifers assemblages ranging from bathyal to abyssal.

\section{INTRODUCTION}

The The abundance of foraminifers in most marine sediments is not for a mere reason as they are absolutely useful especially in biostratigraphy correlation. Benthic foraminifer is a good indicator for ancient environment, due to different species will only be able to restrict habits which resulting them to be abundance in specific niche respectively. Thus, these types of foraminifers are widely used to determine a rock ancient depositional environment. The Temburong Formation is initially named and continued by a research researching the formation [1]. This formation is characterized by flysch deposits of siltstone and shale repetition. Their argillaceous lithology has common intercalations with slight calcareous pelagic shale [2]. Previous researcher concluded that the Temburong Formation is of deep-marine environment by low density turbidity currents [1,3]. The last paleontological studies conducted on this formation are by a scientist on planktonic foraminifers concluded that the formation age range from Late Oligocene to late Early Miocene. The aim for conducting this research is to identify the existence of foraminifer's species and its respective depositional environment focusing on benthic foraminifers using standard micropaleontological method.

\section{GENERAL GEOLOGY}

Labuan Island consists of four lithological units which are Crocker Formation, Temburong Formation, Setap Shale Formation and Belait Formation [4-7]. A geological map (Figure 1) of the research study area was build based on a study with several modifications [8]. The oldest formation is the Crocker Formation followed by the Temburong Formation characterized by a deep-marine deposition [8,1]. The Temburong Formation was formed during the deposition of the Oligocene to Upper Miocene along with the West Crocker Formation according to the basin filling of the Tertiary depocentre of North West Sabah Basin [9-11]. A slight different lithological unit with Crocker Formation which consists of interbedded siltstone and shale, and thick shale unit [12].

Labuan Island was first geologically researched during J. Motley first visit in 1852 on agricultural potential along with lithological and stratigraphy thickness about Kubong Bluff. Another research recorded in a report is on coal deposits by Captain Sir Edward Belcher on his way to H.M.S Semarang. Carl Schmidt did his research on oil and gas occurrence offshore along with the Labuan Exploration Company Limited in 1919 until 1920. A research work on The Geology of the Colony of Borneo was recorded but incomplete until Shell Group restarted that made one of the first geological mapping of Labuan and surrounding areas.

A latest research on Labuan was about foraminiferal occurrence was by a scientist which was focused on the Miocene assemblages which was done in Setap Shale Formation and concluded the blooming of species during Late Early Eocene and said that it was of shallow marine deposition aging Early Miocene. A research on the Temburong Formation done in Tenom and concluded two biozones of foraminiferal which are Globorotalia Zone (P22) and Catapcydrax dissimilis-Praeorbulina sicana Zone (N7) aged Chattian (Late Oligocene) and Burdigalian (Late Early Miocene) respectively. Another research in Labuan Island was on agglutinated foraminifera of Miocene sedimentation. Unfortunately, the Temburong Formation was not directly discussed on the paper.

\section{METHODOLOGY}

The research was done with a total of 15 samples of mudstones and shale of Temburong Formation. Preparation of samples was done step by step following based on Armstrong. A crushed sample of shale was prepared in the laboratory by boiling. A quarter of a $500 \mathrm{ml}$ of beaker was filled with shale sample and mixed with distilled water for the rest. The mixture was then added a decomposing agent, Sodium Bicarbonate and boiled for averagely 2 hours.

Then, the samples were cleaned and left in an oven for it to dry. Dried samples were brought for selection and identification of foraminiferal under binocular microscope. Photograph of well-preserved specimens was taken using image analyzer microscope by Leica. A clear photograph was used for further identification of species using previous research and references [13-16] 

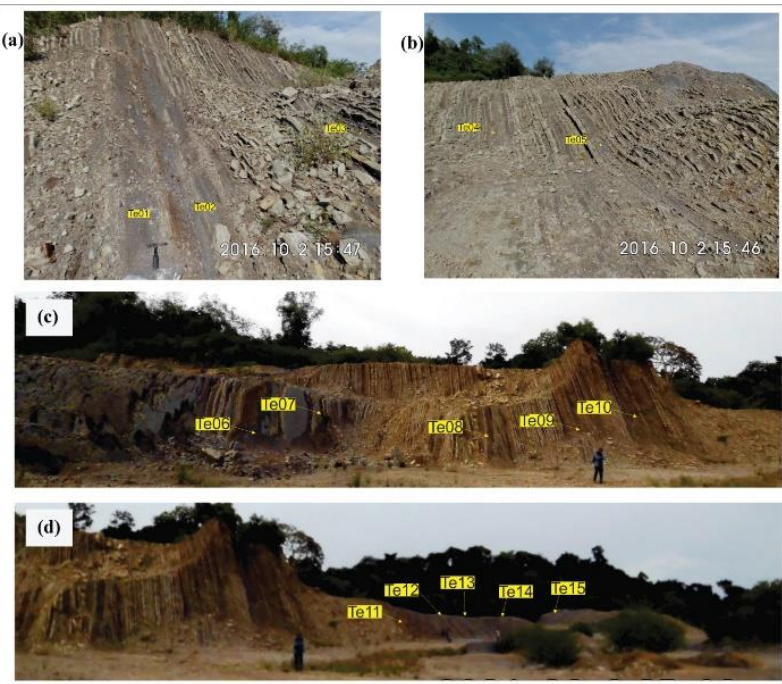

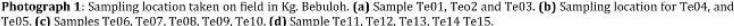

Photograph 1: Sampling location taken on field in Kg. Bebuloh. (a) Sample $\mathrm{Te} 01, \mathrm{Te} 2$ and $\mathrm{Te} 03$. (b) Sampling location for $\mathrm{Te} 04$, and $\mathrm{Te} 05$. (c) Samples Te06, Te07, Te08, Te09, Te10. (d) Sample Te11, Te12, Te13, Te14 Te15.

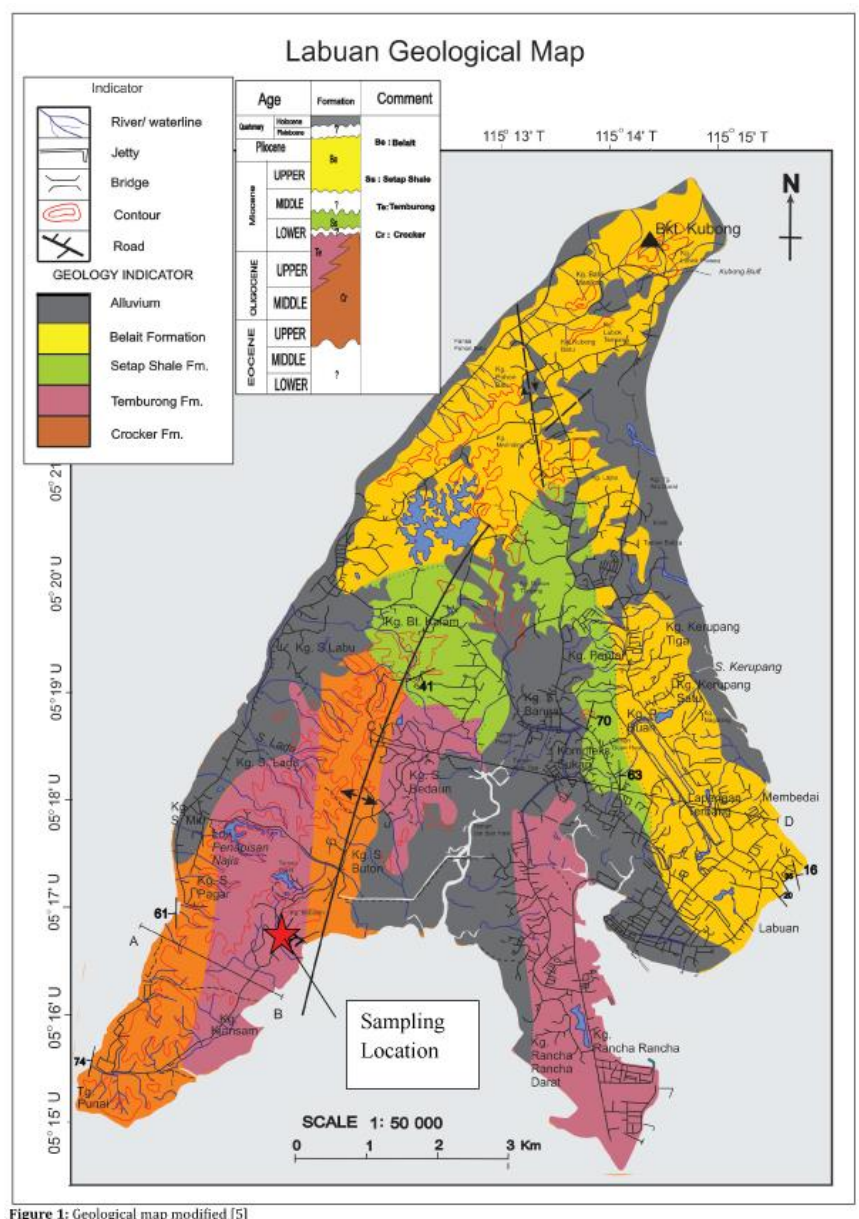

Figure 1: Geological map modified [5]

\section{RESULT}

Out of fifteen samples brought from the outcrops, twelve of it was successfully extracted to have benthic foraminifera which majorly consist of agglutinated and hyaline group. The species or genus was taken as references for its respective bathymetry level using several papers and books as references. Figure 2 and Figure 3 shows illustration of the selected benthic foraminifera.

The following genera and species of benthic foraminiferal found are arranged based on using some research study. Species found was majorly agglutinated and calcareous walled with a total of 19 genuses was collected of a perfect specimen.

\subsection{Taxonomic Note}

\subsubsection{Ammosphaeroidina sp.}

Plate 1- figs.1, 2, 3

The species was formerly known as Cystamminella pseudopauciloculata by Majatliuk (1966). Taxonomy: Genus Ammosphaeroidina Cushman 1910

Order Foraminiferida, Suborder Textulariina, Superfamilia Haplophragmiacea, Familia Ammosphaeroidinidae, Subfamilia Ammosphaeroidininae, Genus Ammosphaeroidina

Occurrence: 405 specimens from 12 samples

Feature: This specimen has a test that is enrolled streptospirally with an involute and three chambers that shows in outer whorl. Shape of the chamber is spherical, tightly embraced which increase rapidly in size. While the aperture is a basal slit, when visible, the walls are surrounded by a perforated wall of finely agglutinated surface. Bathymetry: Outer Neritic to Abyssal

\subsubsection{Bathysiphon sp.}

Plate 1- figs. 10,14,15,16

Taxonomy: Genus Bathysiphon Sars 1872

Order Foraminiferida, Suborder Textulariin, Superfamilia Astrorhizacea, Familia Bathysiphonidae, Genus Bathysiphon Occurrence: 93 specimens from 7 samples (Te01, Te02, Te03, Te04, Te10, $\mathrm{Te} 11, \mathrm{Te} 12)$

Feature: all specimens included were of a tubular test, a thick to medium wall, varying in size. They have a fine grain and smooth wall with positively no branching and a simple terminal aperture.

Bathymetry: Upper to Lower Abyssal

\subsubsection{Bolivina pisciformis Galloway \& Morrey from Renz, 1948}

Plate 2-figs.4

Taxonomy: Genus Bolivina d'Orbigny 1839

Order Foraminiferida, Suborder Rotaliina, Superfamilia Bolivinacea, Familia Bolivinidae Genus Bolivina

Occurrence: 2 specimens of 2 samples (Te01, Te03)

Feature: Biserial test, compressed side view and visible chamber extending fromcentre tooth plate to the outer with strong curvature. Bathymetry: Abyssal

\subsubsection{Brizalina alazanensis Kender 2008 (Bolivina alazanensis Cushman 1926)}

Plate 2 -figs. 2

Taxonomy: Genus Brizalina Costa 1856

Order Foraminiferida, Suborder Rotaliina, Superfamilia Bolivinacea, Familia Bolivinidae, Genus Brizalina

Occurrence: 1 specimen (Te03)

Feature: Consist of biserial test that elongate upwards more than width Compressed side view, chambers are many but seven to eight visible divided by curved and depressed sutures. Perforation of the wall can be seen but considerably smooth with aperture clearly seen from base extending with tooth plate. Bathymetry: Abyssal

\subsubsection{Brizalina aliformis Houlborn 2013}

Plate 2-figs.3

Originally designed as Bolivina Mexicana Cushman var. aliformis Cushman 1926

Occurrence: 1 specimen (Te03)

Feature: an elongated and strongly compressed test that can be seen as biserial growth series. The test are surrounded by keel almost transparent, with chambers imbricating the younger part of the next chamber, separated by strongly curved limbate. Sutures seen are becoming thicker along the centre part of the test with numerous chamber of calcareous wall but finely perforated. Aperture can be seen like a loop with lip. Bathymetry: Abyssal

\subsubsection{Caudammina excelsa Houlborn et al. 2013 (Dylazanka), 1923}

Plate 1-figs. 11

Taxonomy: Globothalamea (Class), Textulariia (Subclass), Lituolida (Order), Hormosinina (Suborder), Hormosinelloidea (Superfamily), Hormosinellidae (Family), Caudammina (Genus)

Occurrence: 5 specimens of 4 samples (Te01, Te03, Te11, Te12)

Feature: the test is elongated with uniserial growth with rectilinear 
triangular-shaped chamber. They are connected with thick stolons, with thick walls the chamber are finely agglutinated. An aperture is terminal round.

Bathymetry: Abyssal

\subsubsection{Cibicidoides barnetti (Bermudez) 1949}

Plate 2-figs. 12

Taxonomy: Genus Cibicidoides Thalmann 1939 Order Foraminiferida, Suborder Rotaliina, Superfamilia Discorbinellacea, Familia Parrelloididae, Genus Cibicidoides Occurrence: 4 specimens of 4 samples (Te1, Te2, Te3, Te11)

Feature: Trochospiral tests, biconvex cross-section, convex side view, limbate sutures extending along periphery forming pseudokeel. Wall are calcareous and thick with uniform perforation on both side, aperture is slit and narrow at the spiral side.

Bathymetry: Bathyal

\subsubsection{Cibicidoides bradyi Trauth 1918}

Plate 2-figs.14

Taxonomy: Genus Cibicidoides Thalmann 1939

Order Foraminiferida, Suborder Rotaliina, Superfamilia Discorbinellacea, Familia Parrelloididae, Genus Cibicidoides

Occurrence: 5 specimens from 3 samples (Tte02, Te03, Te09)

Feature: Trochospiral tests, unequally biconvex cross-section, rounded periphery, inflated chamber mostly nine to ten in the last whorl and separated by radial sutures. Calcareous walls with coarse perforation on spiral side but smooth perforated on the umbilical side. Aperture are narrow and slit opening with lips extending onto the spiral side.

Bathymetry: Bathyal to abyssal.

\subsubsection{Cyclammina sp. 1}

Plate 2- figs. 15

Taxonomy: Genus Cyclammina Brady 1879

Order Foraminiferida, Suborder Textulariina, Superfamilia Loftusiacea, Familia Cyclamminidae, Subfamilia Cyclammininae, Genus Cyclammina

Occurrence: 1 specimen only (Te01)

Feature: A fraction of a large test, consist of 10 to 12 visible chambers, planispiral with large aperture. The convex shape of it is surrounded by agglutinated wall.

Bathymetry: Abyssal

\subsubsection{Cyclammina sp. 2}

Plate 2- figs. 16

Kender et al. 2008

Occurrence: 1 Specimen (Te01)

Feature: Smaller test compare to Cyclammina sp. 1, with a glossy test. The walls are perforate-like feature with sutures are depressed and can be seen 13 to 15 chambers. It also has a large aperture in the apertural face. Bathymetry: Abyssal

\subsubsection{Cyclammina sp. $3 / 4$}

Plate 2- figs.17,18

Taxonomy: Genus Cyclammina Brady 1879

Order Foraminiferida, Suborder Textulariina, Superfamilia Loftusiacea, Familia Cyclamminidae, Subfamilia Cyclammininae, Genus Cyclammina

Occurrence: 1 Specimen (Te01)

Feature: a very large test measuring up to $1 \mathrm{~mm}$ with involute shape, planispiral and have a thickness almost halves of its wide. The walls are of coarse grain, sutured by depressed lines which became sigmoidal in later stages. Apertures seen is basal-slit shaped.

Bathymetry: Abyssal

\subsubsection{Gyroidinoides girardanus (Reuss), Beckmann 1953}

Plate 2-figs.13

Taxonomy: Genus Gyroidinoides Brotzen 1942

Order Foraminiferida, Suborder Rotaliina, Superfamilia Chilostomellacea, Familia Gavelinellidae, Subfamilia Gyroidinoidinae, Genus Gyroidinoides

Occurrence: 2 specimens from 1 sample (Te03)

Feature: Smooth wall, with 8 or 9 chambers of the last whorl for the specimen. Aperture is basal slit with large opening and slightly inflated.

Bathymetry: Abyssal
4.1.12 Hanzawaia mantaensis Galloway and Morrey, 1929

Plate 2- figs.11

Taxonomy: Genus Hanzawaia Asano 1944

Order Foraminiferida, Suborder Rotaliina, Superfamilia Chilostomellacea, Familia Gavelinellidae, Subfamilia Gavelinellinae, Genus Hanzawaia

Occurrence: 15 specimens of 7 samples (Te1, Te2, Te3, Te7, Te10, Te11, $\mathrm{Te} 12)$

Feature: Test of a low trochospiral with sutures strongly curved, smooth wall with perforation slight, slit aperture present at the base of apertural face, slightly convex shape.

Bathymetry: Upper to middle bathyal, occasionally neritic and lower bathyal

\subsubsection{Lagena Striata d'Orbigny, 1839}

Plate 1- figs. 17

Taxonomy: Genus Lagena Walker \& Jacob 1798

Order Foraminiferida, Suborder Lagenina, Superfamilia Nodosariacea, Familia Lagenidae, Genus Lagena

Occurrence: 1 specimen (Te01)

Feature: a spherical test shape with sutures vertically dense along the sphere. A long neck present with terminal aperture at the apertural face. Bathymetry: Abyssal

\subsubsection{Marssonella oxycona Reuss 1866}

Plate 1-figs. 5

Taxonomy: Genus Marssonella Cushman 1933

Ordo Foraminiferida, Subordo Textulariina, Superfamilia Textulariacea, Familia Eggerellidae, Subfamilia Dorothiinae, Genus Marssonella

Occurrence: 1 specimen (Te11)

Feature: Test forms a stout, started with trochospiral cone elongating and later with biserial growth and flat or slight concave terminal face.the chamber separated by indistinct sutures called flush. Walls are canaliculated and most of calcareous materials and cement.

Bathymetry: Bathyal to abyssal

\subsubsection{Nodosaria anomala Reuss 1866}

Plate 1- figs. 1

Taxonomy: Genus Nodosaria Lamarck 1812

Order Foraminiferida, Suborder Lagenina, Superfamilia Nodosariacea, Familia Nodosariidae, Subfamilia Nodosariinae, Genus Nodosaria

Occurrence: 3 specimens of 3 samples (Te01, Te10, Te12)

Feature: with a uniserial test and elongating shape, the specimen has six to seven globular chambers either ovoid or spherical shape. The chambers size increase gradually slow and ended with a terminal aperture opening. Bathymetry: Upper Abyssal

\subsubsection{Nothia robusta Kender et al. 2008 (Grzybowski 1898)}

Plate 1-figs. 9

Taxonomy: Genus Nothia Pflaumann 1964

Order Foraminiferida, Suborder Textulariina, Superfamilia Astrorhizacea, Familia Bathysiphonidae, Genus Nothia

Occurrence: 5 specimens from 3 samples (Te01, Te11, Te12)

Feature: species are quite large, robust and tubular. They are reported to be rarely branching with in constriction or inflation, straight or slightly curved shape.

Bathymetry: Upper Abyssal

4.1.17 Plectofrondicularia vaughani Cushman 1927

Plate 2-figs. 1 
Taxonomy: Genus Plectofrondicularia Liebus 1902

$\begin{array}{llr}\text { Ordo Foraminiferida, Subordo Lagenina, } & \text { Superfamilia } \\ \text { Nodosariacea, Familia Nodosariidae, } & \text { Subfamilia } \\ \text { Plectofrondiculariinae Genus Plectofrondicularia } & \end{array}$
Plectofrondiculariinae, Genus Plectofrondicularia

Occurrence: 1 specimen (Te01)

Feature: Test elongate and forms biserial into uniserial series. Slight inflated chambers with uniserial part arched centrally. The chambers have curved strong sutures on a calcareous wall which is finely perforated and an aperture of radial or denticulate rim shape.

Bathymetry: Lower Neritic To Middle Bathyal

\subsubsection{Pseudonodosinella troyeri Houlborn 2013 (Tappan) 1960}

Plate 1-figs. 8

Taxonomy: Genus Pseudonodosinella Saidova 1970

Order Foraminiferida, Suborder Textulariina, Superfamilia Hormosinacea, Familia Hormosinidae, Subfamilia Hormosininae, Genus Pseudonodosinella

Occurrence: 2 specimens of a sample ( $\mathrm{Te} 01)$

Feature: Test consists of small, elongated and flattened of a uniserial series. Globular of three to six can be seen overlapping the later and separated by horizontal sutures. Finely agglutinated walls, with multi layered and smooth have a simple terminal aperture.

Bathymetry: Bathyal to abyssal

\subsubsection{Pyramidulina stainforthi (Cushman Renz) Bolli 1994}

Plate 1- figs. 13

Same as Nodosaria stainforthi Cushman and Renz, 1941

Taxonomy: Genus Pyramidulina Fornasini 1894

OrderForaminiferida, Subordo Lagenina, Superfamilia Nodosariacea, Familia Nodosariidae, Subfamilia Nodosariinae, Genus Pyramidulina

Occurrence: 2 specimens of 2 samples (Te01, Te03)

Feature: uniserial test that is rectilinear, elongating with spherical chamber but hexagonal with cross section. Longitudinal costae are extending along the test and become thicker as it meets the suture and aperture. A terminal aperture can be seen.

Bathymetry: Neritic to Bathyal

\subsubsection{Reophax cf. troyeri Houlborn et al. 2013}

Plate 1- figs. 12

Taxonomy: Genus Reophax Montfort 1808

Order Foraminiferida, Suborder Textulariina, Superfamilia Hormosinacea, Familia Hormosinidae, Subfamilia Reophacinae, Genus Reophax

Occurrence: 2 specimens of 1 sample (Te01)

Feature: The specimen is quite unclear but it can be seen as a uniserial series which elongate and consist of multilocular chamber.

Bathymetry: Lower Bathyal

\subsubsection{Textularia agglutinans d'Orbigny, 1839}

Plate 1- figs. 6

Taxonomy: Genus Textularia Defrance 1824

Order Foraminiferida, Suborder Textulariina, Superfamilia Textulariacea, Familia Textulariidae, Subfamilia Textulariinae, Genus Textularia

Occurrence: 2 specimens of 2 samples (Te1, Te11)

Feature: agglutinated tests, with numerous chambers stacking each other.the chambers look like a braided figure ended with rounded chamber. Aperture clearly can be seen at the end with basal slit opening. Bathymetry: Abyssal

\subsubsection{Textularia Truncata Höglund, 1947}

Plate 1- figs. 7

Taxonomy: Genus Textularia Defrance 1824
Order Foraminiferida, SuborderTextulariina, Superfamilia Textulariacea, Familia Textulariidae, Subfamilia Textulariinae, Genus Textularia

Occurrence: 2 specimens of 2 samples (Te1, Te12)

Feature: The agglutinated walls made the chambers look quite unclear but can be seen it is interfingering with corresponds chamber. The last chamber can be clearly seen elevated slightly than the one before making it a cupped-like feature. The triangular test has slit aperture with coarsewalled.

Bathymetry: Bathyal to Abyssal

\subsubsection{Uvigerina basicordata Cushman and Renz, 1941}

Plate 2- figs. 10

Original: U. gallowayi Cushman var. basicordata Cushman and Renz 1941 Taxonomy: Genus Uvigerina d'Orbigny 1826

Ordo Foraminiferida, Subordo Rotaliina, Superfamilia Buliminacea, Familia Uvigerinidae, Subfamilia Uvigerininae, Genus Uvigerina

Occurrence: 1 specimen (Te01)

Feature: an almost rectangular test with triserial growth, longer than wider especially the midlle part of it. The walls have four to five longitudinal basal spines, on a chamber that increases in size greatly at later stages, separated by depressed sutures. A thin elongated neck has terminal apertures at the end bordered by a phialine lip. Bathymetry: Bathyal

\subsubsection{Uvigerina Hispida Schwager 1866}

Plate 2-figs. 8

Occurrence: 6 specimens of 5 samples (Te01Te02, Te03, Te11, Te12)

Feature: the test seen is triserial series which elongate in adult one. Length should be as twice as the width but widest part is the one nearest to the apertural face. Size of chambers increases fast as it grows but the chambers are inflated with fine perforation, hispid wall, covered with narrow spines all over the chamber wall. A short-raised neck holds a round-shaped aperture.

Bathymetry: Upper Abyssal

\subsubsection{Uvigerina mantaensis Cushman and Edwards 1938}

Plate 2-figs. 7

Occurrence: 2 specimens of 2 samples (Te03)

Feature: test is triserial and elongating twice than its width. The widest part is the one in middle part of test seen with chambers. The strongly inflated chamber has depressed sutures and finely perforated with fine numerous hisps. A raised neck also presents along with aperture but slightly depressed.

Bathymetry: Lower Abyssal

\subsubsection{Uvigerina proboscidea Schwager 1866}

Plate 2- figs. 6

Occurrence: 2 specimens from 2 samples (Te03, Te12)

Feature: A triserial test grows becoming biserial test that elongated twice the width. Central part has the widest width with initial end rounded shaped. Chambers size increases rapidly but inflated especially the central one, sutures are depressed distinctly showing the perforated wall with denser short hisps. A raised neck with rounded aperture is present.

Bathymetry: Lower Abyssal

\subsubsection{Valvulina flexilis Cushman \& Renz 1941 (Bolli et al., 1994)}

Plate 1- figs. 4

Taxonomy: Genus Valvulina d'Orbigny 1826

Ordo Foraminiferida, Subordo Textulariina, Superfamilia Textulariacea, Familia Valvulinidae, Subfamilia Valvulininae, Genus Valvulina

Occurrence: 3 specimens from 2 samples (Te01, Te11)

Feature: The test is triserial series that enlarge rapidly as it grows and last three chambers are distinctly bigger that the other. It has periphery that lobulate slight in shape but rounded and inflated chambers can be seen along with depressed sutures. Aperture found at the end of apertural face, arching with flattened tooth. 


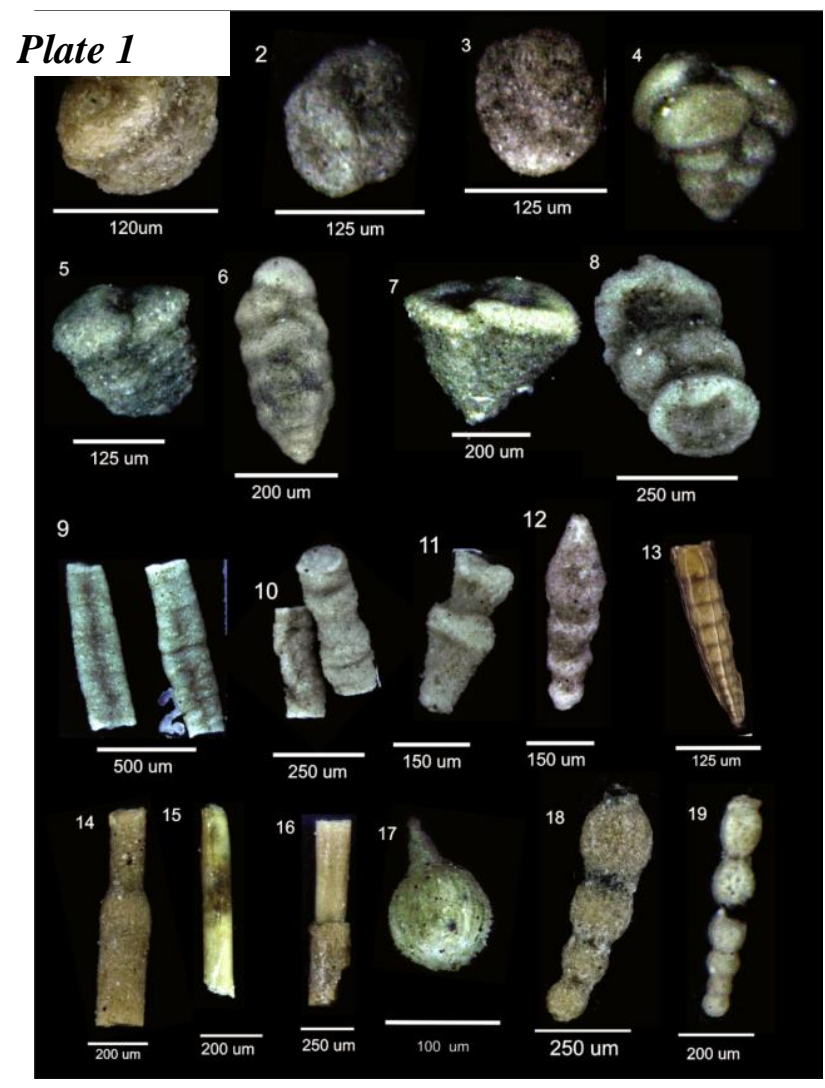

Figure 2: Illustration of benthonic foraminifera found in Temburong Formation.

1-3 Ammosphaeroidina sp. Mjatliuk, 1966; 4. Valvulina flexilis; Cushman \& Renz, 1941; 5. Marsonella oxycona Reuss, 1866; 6. Textularia agglutinans d'Orbigny, 1839; 7. Textularia truncate Höglund, 1947; 8. Pseudonodosinella troyeri (Tappan) 1960; 9. Nothia robusta; 10. Bathysiphon discretus Sars 1872; 11. Caudammina excelsa,Dylazanka 1923; 12. Rheophax troyeri Houlborn et al.? 2013; 13. Pyramidulina stainforthi (Cushman \& Renz) Bolli 1994; 14-16. Bathysiphon sp.; 18. Nodosaria rudis?; 19. Nodosaria anomala Reuss 1866.

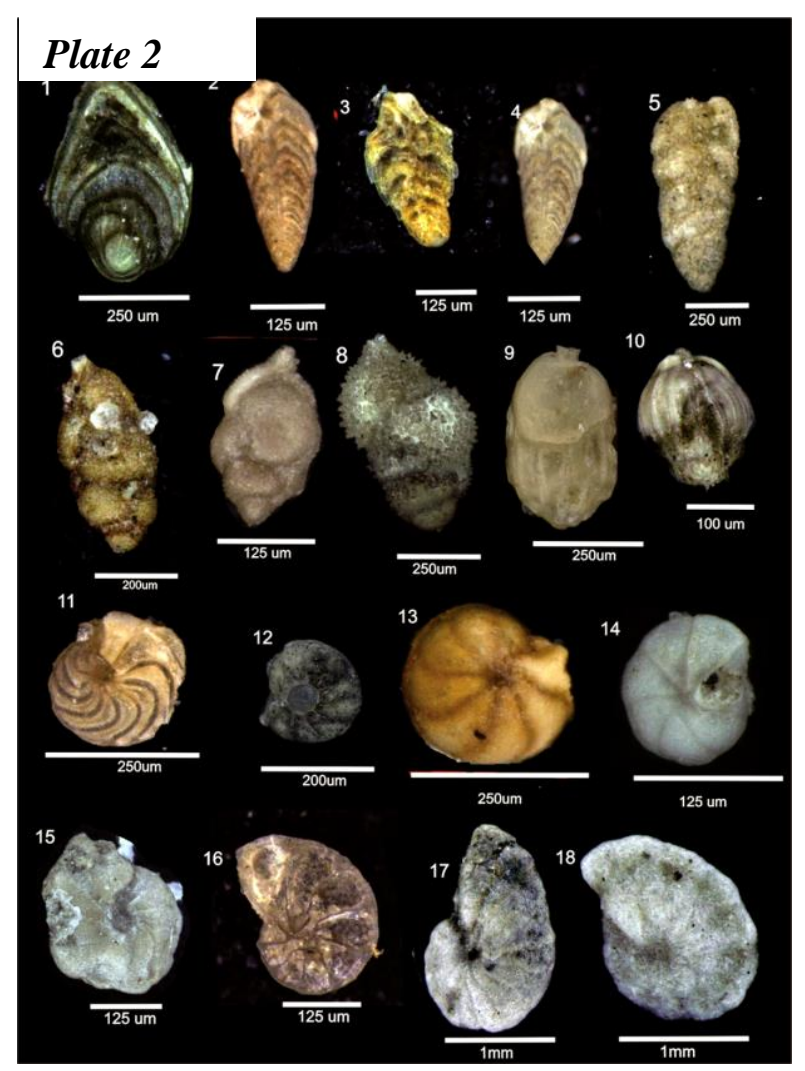

Figure 3: Illustration of results for benthic foraminifera.

1. Plectofrondicularia vaughani Cushman 1927; 2. Bolivina alazenensis venezuelana Kender ,2008 \& Cushman 1926; 3. Bolivina mexicana aliformis from Cushman 1926; 4. Bolivina pisciformis Galloway \& Morrey (Renz, 1948); 5. Bolivina sp.; 6. Uvigerina proboscidea Schwager 1866; 7. Uvigerina mataensis Cushman and Edwards, 1938; 8. Uvigerina hispida Schwager 1866; 9. Uvigerina gallowayi; 10. Uvigerina basicordata Cushman and Renz, 1941; 11. Hanzawaia mantaensis Galloway and Morrey, 1929; 12. Cibicidoides barnetti (Bermudez) 1949; 13 Gyroidinoides girardanus (Reuss), Beckmann 1953; 14. Cibicidoides bradyi Trauth 1918; 15. Cyclammina sp.Kender 2008?

\section{DISCUSSION}

Generally, all the samples that were successfully extracted consist majorly of agglutinated foraminifera and several hyaline groups. All the identified genus and species before was used to do analysis of bathymetry and is presented in Table 1 . A total of 37 species were perfectly extracted.

Agglutinated type benthic is collected the most exceeding 50 specimens per samples, for examples the Ammosphaeroidina sp., Bolivina sp.,Bathysiphon sp., Nothia robusta, Textularia agglutinans, Textularia truncate and more. The entire sample represents the Temburong Formation. Ammosphaeroidina sp.is common species present in lower bathyal assemblages and is a dominant species for almost all the samples. Bathysiphon sp., Caudammina excelsa, Cibicidoides barnetti, Cibicidoides bradyi, Marsonella oxycona, Plectofrandicularia vaughani, Pyramidulina stainforthi, Reophax troyeri, Textularia truncata, and Uvigerina basicordata is an assemblage indicating Bathyal to Abyssal environment.

Meanwhile, Bolivina sp. and its genus, Cyclammina sp., Gyrodinoides girardanus, Hanzawaia mantaensis, Lagena striata, Nodosaria rudis, Textularia agglutinans, Bathysiphon discretus, Bathysiphon sp., Nodosaria anomala, Nothia robusta and Uvigerina hispida are grouped as the assemblages of abyssal environment. Thus, it can be stated that the samples and the formation of the outcrop is deposited in bathyal to abyssal environment. All the species recorded are present in Upper Abyssal condition which could be the exact depositional of the sediments.

The species found show some distinction with previous work of a researcher, where several species is either absent or badly preserved specimen. Karreriella $s p$., and Trochammina $s p$. was merely found to absent making the assemblages of certain are quite incomplete. The depth of research including distribution of species in paleoenvironments should be done to further the research and depositional modeling based on benthic assemblages and distribution.

A different research on benthic foraminifera was done by a researcher the Kudat Formation and the Crocker Formation on smaller benthic presence in mudstone. With high number of agglutinated and calcareous benthic present, the assemblage of foraminifera for Kudat Formation was said to be sediments ranging from bathyal to neritic. Meanwhile, Temburong Formation is of Bathyal to Abyssal range.

Table 1: Tabulation of foraminifers' distribution in the samples

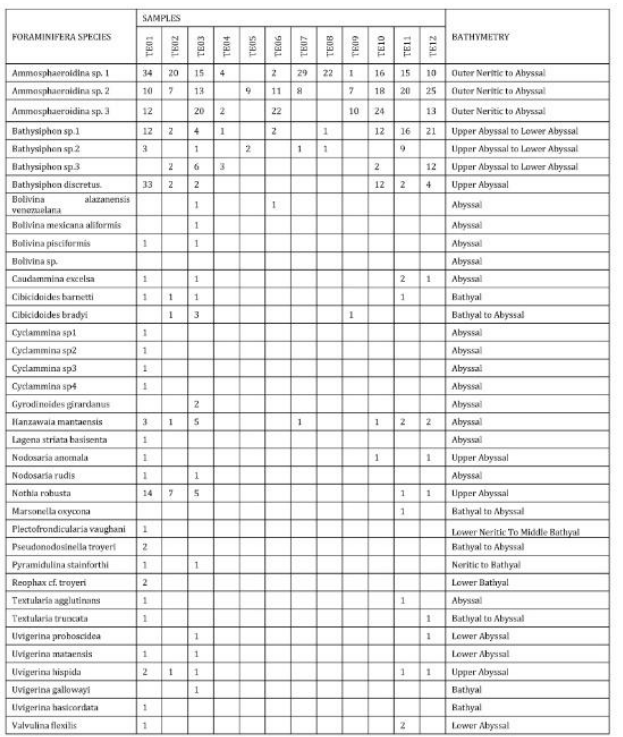




\section{CONCLUSION}

The benthic foraminifera of the Temburong Formation are rich in deep sea agglutinated foraminifera consisting of two major assemblages measured up to sedimentation environment from bathyal to abyssal. All of the species found are mostly in upper abyssal depth environment.

\section{ACKNOWLEDGEMENT}

The first Author is very thankful to University Malaysia Sabah for giving full support on this research under the grant scheme of UMSGreat 2016. Appreciation is given to anyone who helped and supported this research along the way either during field or else.

\section{REFERENCES}

[1] Wilson, R.A.M. 1964. The geology and mineral resources of the Labuan and Padas Valley area, Sabah, Malaysia. Geological Survey of the Borneo Region of Malaysia, Memoir 17.

[2] Hutchison, C.S. 1996. The 'Rajang accretionary prism' and 'Lupar Line' problem of Borneo. In: Hall, R. \& Blundell, D. (Eds.), Tectonic Evolution of Southeast Asia. Geol Soc. of London Special Publication 106, 247-261.

[3] Asis, J., Tahir, S., Rahim, A.R., Konjing, Z., Kob, R.C., Tija, H. D. 2017. Smaller benthic foraminifera analysis of Kudat formation, Kudat, Sabah: Preliminary Intrepertation. Geological Behaviour Publication.

[4] Jasin, B., Tahir, S.H., and Tating, F. F. 1991. Late Eocene Planktonic Foraminifera from the Crocker Formation, Pun Batu, Sabah. Warta Geologi, 17 (4), 187-191.

[5] Tahir, S.H., Musta, B., and Mansor, H.E. 2011. Facies Analysis Of Late Miocene Belait Formation Of Labuan. National Conference 2011, Malaysia, $39-41$.

[6] Armstrong, H.A. and Brasier M.D. 2005. Microfossils. 2nd edition. United Kingdom. Blackwell Publishing.
[7] Motley, J. 1852. Report on the Geological Phenomenon on the islan of Labuan and neighbourhood: The Journal of the Indian Archipelango and Eastern Asia.

[8] Bidgood, M. D., Simmons, M. D., and Thomas, G. G. C. 2000. Agglutinated Foraminifera from Miocene sediments of Northwest Borneo. United Kingdom.

[9] Houlbrn, A., Henderson, A.S., and MacLeod, N. 2013. Atlas Of Benthic Foraminifera. John Wiley and Sons, Ltd., Publication. West Sussex.

[10] Bolli, H.M., Beckmann, J. P., and Saunders, J. B., 1994. Benthic Foraminiferal Biostratigraphy of the South Caribbean Region. Cambridge University Press. Great Britain.

[11] Kender, S., Kaminski M.A., and Jones, R. W. 2008. Early to Middle Miocene foraminifera from the deep-sea Congo Fan, Offshore Angola. Micropaleontology, 54 (6), 477-568.

[12] Kaminski, M. A., Gradsrein, F. M., Bäckström, S., Berggren, W. A., Bunik, M., Carvajal-Chitty, H., Filipescu, S., Geroch, S., Jones, G.D., Kuhnt, W., McNeil, D. H., Nagy, J., Platon, E., Ramesh, P., Rögl, F., Thomas, F.C., Whittaker, J. E., Yakovleva-)'Neil, S. 2005. Atlas of Paleogene Cosmopolitan Deep-Water Agglutinated Foraminifera. Grzybowski Foundation Special Publication 10, $545+$ vii pp.

[13] Haynes, R.J. 1981. Foraminifera. Macmillan Publisher, LTD. London.

[14] Asis, J., Rahman, M.N.I.A., Jasin, B., and Tahir, S. 2015. Late Oligocene and Early Miocene planktic foraminifera from the Temburong Formation, Tenom, Sabah. Bulletin of the Geological Society of Malaysia, 61, December 2015.

[15] Madon, M. 1999. North Luconia Province. The Petroleum Geology and Resources of Malaysia, chapter 19, Petroliam Nasional Berhad (PETRONAS), Kuala Lumpur, 443-454.

[16] Tahir, S.H., and Musta, B. 2007. Pengenalan Kepada Stratigrafi. Penerbit Universiti Malaysia Sabah. Kota Kinabalu. 